Original Article

\title{
Analisis Faktor Penghambat Kepala Keluarga dalam Kepemilikan Jamban Keluarga
}

\author{
Analysis of The Inhibiting Factors of Family Heads in Family Latrine Ownership \\ Fadel Achmad Haikal*, Vera Yulyani, Dhiny Easter Yanti \\ Universitas Malahayati \\ (*fadelachmadhaikal14@gmail.com)
}

\begin{abstract}
ABSTRAK
Tujuan penelitian untuk menganalisis faktor penghambat kepala keluarga dalam kepemilikan jamban keluarga. Jenis penelitian yang digunakan dalam penelitian ini adalah metode kuantitatif dengan desain study cross sectional. Teknik pengambilan yaiu probabilitas sampling. Data primer peneitian meliputi karakteristik responden seperti jenis kelamin, Suku, Pendidikan terakhir dan Pekerjaan. Adapun variabel penelitian meliputi kepemilikan jamban, motivasi, sosial ekonomi dan tingkat pengetahuan. Analisis data menggunakan SPSS 22.0 dengan uji chi square kemaknaan 95\%. Hasil penelitian menunjukkan bahwa adanya hubungan motivasi dengan kepemilikan jamban ( $p$-value 0,002$)$, ada hubungan antara sosial ekonomi dengan kepemilikan jamban ( $p$-value $0,010, \mathrm{OR}=6,100)$, dan ada hubungan antara pengetahuan dengan kepemilikan jamban ( $p$-value $0,029, \mathrm{OR}=3,739$ ). Kesimpulan yaitu faktor penghambat kepala keluarga dalam kepemilikan jamban keluarga adalah rendahnya motivasi, rendahnya sosial ekonomi dan pengetahuan yang kurang baik di Desa Kedaung Kecematan Pardasuka.
\end{abstract}

Kata kunci: Kepemilikan jamban, motivasi, sosial ekonomi, pengetahuan

\section{ABSTRACT}

The research objective was to analyze the inhibiting factors of the head of the family in owning a family latrine. This type of research used in this research is a quantitative method with a cross sectional study design. The technique of taking is probability sampling. The primary data of this research includes the characteristics of the respondents such as gender, ethnicity, latest education and occupation. The research variables include latrine ownership, motivation, socio-economy and level of knowledge. Data analysis used SPSS 22.0 with the chi square test of significance of 95\%. The results showed that there was a relationship between motivation and ownership of a latrine ( $p$-value 0.002), there was a socioeconomic relationship with latrine ownership ( $p$-value 0.010, OR $=6.100$ ), and there was a relationship between knowledge and latrine ownership ( $p$-value 0.029, OR =3,739). The conclusion is that the inhibiting factors for the head of the family in owning a family latrine are low motivation, low socioeconomy and poor knowledge in Kedaung Village, Pardasuka District..

Key words: Latrine ownership, motivation, socio-economy, knowledge

\section{https://doi.org/10.33860/jik.v15i1.383}




\section{PENDAHULUAN}

Rumah tangga yang dikatakatan memiliki akses sanitasi yang layak apabila sanitasi yang digunakan memenuhi persyaratan kesehatan lingkungan yang dilengkapi adanya tanki septik/ Sistem Pengolahan Air Limbah (SPAL) yang digunakan sendiri atau bersamasama. Presentase rumah tangga di Indonesia yang memiliki akses sanitasi layak tahun 2016 mencapai angka $67,80 \%$ dan mengalami peningkatan pada tahun 2017 walaupun tidak naik secara signifikan menjadi $67,89 \%$ dan pada tahun 2018 mengalami peningkatan lagi dengan angka $69,27 \%{ }^{1}$.

Data WHO/UNICEF menyatakan bahwa Indonesia adalah negara kedua terbesar di dunia yang penduduknya masih mempraktikkan buang air besar sembarangan (BABS). Keadaan itu menyebabkan sekitar 150.000 anak Indonesia meninggal setiap tahun karena diare dan penyakit lain yang disebabkan sanitasi yang buruk. Data terkini dari situs STBM yang dimuat di laman Kementerian Kesehatan RI menunjukan masih ada 8,6 juta rumah tangga yang anggota keluarganya masih mempraktikkan BABS per Januari $2020^{2}$.

Jamban yang sehat merupakan salah satu indikator dari bersihnya lingkungan seseorang yang mencerminkan bagaimana dia membiasakan diri memiliki lingkungan yang bersih $^{3-5}$. Hal ini dikarenakan jamban merupakan tempat yang hampir tiap hari digunakan untuk membuang kotoran manusia, sehingga jika seseorang yang tidak terbiasa disiplin dalam membersihkan jambannya maka dapat dicirikan bahwa dia tidak terbiasa dengan lingkungan yang bersih atau dengan kata lain dia tidak risih terhadap lingkungan yang kotor 6-8

Secara geografis Kecamatan Pardasuka terletak di selatan Kabupaten Pringsewu merupakan daerah yang masih terbilang pedesaan yang masih banyak ditemukan areal perkebunan dan area aliran sungai-sungai yang membuat masyarakat tidak membuang air besar di jamban keluarga pribadi dilihat dari data masih banyak masyarakat yang masih menumpang untuk melakukan $\mathrm{BAB}$ bahkan masih ada yang melaukan BAB Sembarangan. Kondisi kepadatan penduduk yang terus bertambah menuntut adanya pengaturan fasilitas kesehatan penunjang hidup sehat antara lain sumber air bersih dan jamban keluarga ${ }^{9-12}$. Oleh karena itu, sanitasi yang baik di jamban akan berpengaruh terhadap kualitas kesehatan seseorang ${ }^{13,14}$. Program stop buang air besar sembarangan juga mencegah stunting anak ${ }^{15}$. Beberapa penelitian telah mendokumentasikan bahwa buang air besar sembarangan merupakan kendala yang signifikan pada pertumbuhan anak $^{16}$. Literatur medis dan epidemiologi telah mendokumentasikan mekanisme yang menghubungkan antara buang air besar sembarangan dengan hambatan pertumbuhan pada awal kehidupan manusia ${ }^{17}$.

Tujuan penelitian untuk menganalisis faktor penghambat kepala keluarga dalam kepemilikan jamban keluarga di Desa Kedaung Kecamatan Pardasuka.

\section{METODE PENELITIAN}

Penelitian dilaksanakan di Desa Kedaung Kecamatan Pardasuka pada bulan SeptemberDesember tahun 2020. Jenis penelitian yang digunakan dalam penelitian ini adalah metode kuantitatif. dengan desain study cross sectional. Teknik pengambilan sampel yang digunakan dalam penelitian ini dengan menggunakan teknik probabilitas sampling. Pengambilan sampel secara acak dengan menggunakan teknik simpel random sampling. Populasi dalam penelitian ini seluruh kepala keluarga yang berjumlah 526 di Desa Kedaung Kecamatan Pardasuka. Sampel sebanyak 84 yang diambil dari kepala keluarga atau ibu rumah tangga di Desa Kedaung Kecamatan Pardasuka. Rumus besar sampel ${ }^{18}$.

Data primer merupakan data yang diperoleh dari responden meliputi karakteristik responden seperti jenis kelamin, Suku, Pendidikan terakhir dan Pekerjaan. Adapun variabel penelitian meliputi kepemilikan jamban, motivasi, sosial ekonomi dan tingkat pengetahuan. Data primer diperoleh dengan menggunakan kuisioner sedangkan data sekunder diperoleh dari Kantor Kepala Desa Kedaung dan Puskemsmas Paradasuka. Alat ukur atau instrumen yang digunakan telah memenuhi dua syarat validitas dan reliabilitas. Analisis data menggunakan SPSS 22.0 dengan uji chi square kemaknaan $95 \%$ atau p-value $<0,05$. Kelayakan etik penelitian dari komisi Etik Universitas Malahayati Nomor: 1176/EC/Kep-UNMAL/VIII/2020 tanggal 26 Agustus 2020.

\section{HASIL}

Tabel 1 menunjukkan bahwa Mayoritas responden berjenis kelamin perempuan 69\%, 
suku Sunda 85,7\%, berpendidikan dasar 84,5\%, bekerja sebagai ibu rumah tangga 52,4\%. Sebagian besar responden tidak memiliki jamban 78,6\%. memiliki motivasi lemah 48,8\% namun responden yang telah memiliki motivasi kuat sebanyak 29,8\%. Responden yang memiliki sosial ekonomi rendah $86,9 \%$. Responden yang memiliki tingkat pengetahuan kurang baik 58,3\% (tabel 2).

Tabel 1 Distribusi Karakteristik Responden

\begin{tabular}{lrr}
\hline \multicolumn{1}{c}{ Karakteristik } & n & (\%) \\
\hline Jenis Kelamin & & \\
Laki-laki & 28 & 31,0 \\
Perempuan & 58 & 69,0 \\
\hline Suku & & \\
$\quad$ Lampung & 3 & 3,6 \\
Jawa & 7 & 8,3 \\
Padang & 1 & 1,2 \\
Sunda & 72 & 85,7 \\
Palembang & 1 & 1,2 \\
\hline Pendidikan Terakhir & & \\
Tidak Sekolah & 5 & 6,0 \\
Pendidikan Dasar & 71 & 84,5 \\
Pendidikan Menengah & 5 & 6,0 \\
Pendidikan Tinggi & 3 & 3,6 \\
\hline Pekerjaan & & \\
Ibu Rumah Tangga & 44 & 52.4 \\
Pedagang/Wiraswasta & 2 & 2,4 \\
Petani & 35 & 41,7 \\
Buruh & 3 & 3,6 \\
\hline \multicolumn{1}{c}{ Total } & $\mathbf{8 4}$ & $\mathbf{1 0 0}$ \\
\hline
\end{tabular}

Berdasarkan tabel 3 dari 84 responden terdapat $38(92,7 \%)$ responden yang tidak memiliki jamban dengan motivasi lemah, yang tidak memiliki jamban dengan motivasi sedang sebanyak 14 (77,8\%) responden sedangkan Responden yang memiliki tidak jamban dengan motivasi kuat sebanyak 14 (56\%) responden dan dari 84 responden terdapat $3(8,8 \%)$ responden yang memiliki jamban dengan motivasi lemah, yang memiliki jamban dengan motivasi sedang sebanyak $4(3,9 \%)$ responden sedangkan responden yang memiliki jamban dengan motivasi kuat 11 (44\%). Hasil analisis uji Chi Square yang menghambat pembangunan jamban keluarga di Desa Kedaung Kecamatan Pardasuka tahun 2020 menunjukkan bahwa $p$-value $=0,002$ kurang dari $\alpha=0,05$. Artinya bahwa secara statistik ada pengaruh antara motivasi terhadap pembangun jamban keluarga. Berdasarkan tabel 3 dari 84 responden terdapat $61(83,6 \%)$ responden yang tidak memiliki jamban dengan sosial ekonomi rendah, sedangkan yang tidak memiliki jamban dengan sosial ekonomi tinggi sebanyak 5 $(45,5 \%)$ responden. Responden yang memiliki jamban dengan sosial ekonomi rendah sebanyak $12(16,4 \%)$ responden dan $6(54,5 \%)$ responden yang memiliki jamban deangan sosial ekonomi tinggi. Hasil analisis uji $C h i$ Square yang menghambat kepemilikan jamban keluarga di Desa Kedaung Kecamatan Pardasuka tahun 2020 menunjukkan bahwa $p$ value $=0,010$ kurang dari $\alpha=0,05$. Artinya bahwa secara statistik ada pengaruh antara sosial ekonomi terhadap kepemilikan jamban keluarga dengan nilai Odd Rasio (OR) sebesar 6,100 maka secara statistik dapat disimpulkan bahwa responden yang memiliki sosial ekonomi tinggi 6,1 kali lebih berpengaruh terhadap kepemilikan jamban keluarga dibandingkan responden yang memiliki sosial ekonomi rendah.

Tabel 2 Distribusi Variabel Responden

\begin{tabular}{|c|c|c|}
\hline Variabel Penelitian & $\mathbf{n}$ & $(\%)$ \\
\hline \multicolumn{3}{|l|}{ Kepemilikan Jamban } \\
\hline Tidak Memiliki Jamban & 66 & 78,6 \\
\hline Memiliki Jamban & 18 & 21,4 \\
\hline \multicolumn{3}{|l|}{ Motivasi } \\
\hline Motivasi Lemah & 41 & 48,8 \\
\hline Motivasi Sedang & 18 & 21,4 \\
\hline Motivasi Kuat & 25 & 29,8 \\
\hline \multicolumn{3}{|l|}{ Sosial Ekonomi } \\
\hline Penghasilan Rendah & 73 & 86,9 \\
\hline Penghasilan Tinggi & 11 & 13,2 \\
\hline \multicolumn{3}{|l|}{ Tingkat Pengetahuan } \\
\hline Pengetahuan & 49 & 58,3 \\
\hline Baik & 35 & 41,7 \\
\hline \multicolumn{3}{|l|}{ Pengetahuan Baik } \\
\hline Total & 84 & 100 \\
\hline
\end{tabular}

Berdasarkan tabel 3 dari 84 responden terdapat $43(87,8 \%)$ responden yang tidak memiliki jamban dengan pengetahuan kurang baik, sedangkan yang tidak memiliki jamban dengan pengetahuan baik sebanyak $23(65,7 \%)$ responden. Responden yang memiliki jamban dengan pengetahuan kurang baik sebanyak 6 $(12,2 \%)$ responden dan $12(34,4 \%)$ responden yang memiliki jamban deangan pengetahuan baik. Hasil analisis uji Chi Square yang menghambat kepemilikan jamban keluarga di Desa Kedaung Kecamatan Pardasuka tahun 2020 menunjukkan bahwa $P$-Value $=0,031$ kurang dari $\alpha=0,05$. Artinya bahwa secara statistik ada pengaruh antara pengetahuan terhadap pembangun jamban keluarga dengan 
nilai Odd Rasio (OR) sebesar 3,739 maka secara statistik dapat disimpulkan bahwa responden yang memiliki pengetahuan baik 3,7 kali lebih berpengaruh terhadap kepemilikan jamban keluarga dibandingkan responden yang memiliki pengetahuan kurang baik.

Tabel 3 Hubungan Motivasi, Faktor Sosial Ekonomi dan Tingkat Pengetahuan dengan Kepemilikan Jamban Keluarga di Desa Kedaung Kecamatan Pardasuka Kabupaten Pringsewu.

\begin{tabular}{|c|c|c|c|c|c|c|c|}
\hline \multirow{3}{*}{ Variabel } & \multicolumn{4}{|c|}{ Kepemilikan Jamban } & \multirow{3}{*}{ Total } & \multirow{3}{*}{$\begin{array}{c}\text { P- } \\
\text { Value }\end{array}$} & \multirow{3}{*}{ OR } \\
\hline & \multicolumn{2}{|c|}{ Tidak Memiliki } & \multicolumn{2}{|c|}{ Memiliki } & & & \\
\hline & $\mathbf{n}$ & $\%$ & $\mathbf{n}$ & $\%$ & & & \\
\hline \multicolumn{8}{|l|}{ Motivasi } \\
\hline Lemah & 38 & 92,7 & 3 & 7,3 & 41 & \multirow{3}{*}{0,002} & \multirow{3}{*}{ NA } \\
\hline Sedang & 14 & 77,8 & 4 & 22,2 & 18 & & \\
\hline Kuat & 14 & 56 & 11 & 44 & 25 & & \\
\hline Faktor Sosial & & & & & & \multirow{4}{*}{0,010} & \multirow{4}{*}{$\begin{array}{c}6,100 \\
(1,600- \\
23,262)\end{array}$} \\
\hline \multicolumn{6}{|l|}{ Ekonomi } & & \\
\hline Rendah & 61 & 83,6 & 12 & 16,4 & 54 & & \\
\hline Tinggi & 5 & 45,5 & 6 & 54,5 & 30 & & \\
\hline \multicolumn{7}{|l|}{ Tingkat Pengetahuan } & \multirow{3}{*}{$\begin{array}{c}3,739 \\
(1,241- \\
11,267)\end{array}$} \\
\hline Kurang baik & 43 & 87,8 & 6 & 12,2 & 54 & 0,031 & \\
\hline Baik & 23 & 65,7 & 12 & 34,4 & 30 & & \\
\hline
\end{tabular}

\section{PEMBAHASAN}

Berdasarkan penelitian yang telah dilakukan di Desa Kedaung motivasi masyarakat desa tersebut masih tergolong lemah karena sebagian besar masyarakat tidak memiliki jamban keluarga yang sehat sehingga tidak adanya dorongan bagi masyarakat untuk kepemilikan jamban keluarga yang sehat. Masyarakat di desa tersebut lebih memilih buang air besar di sungai atau di kebun karena itu sudah menjadi kebiasaan dari masyarakat tersebut dan tidak menjadikan jamban sehat sebagai kebutuhan untuk buang air besar. Semakin banyak masyarakat yang memiliki dan menggunakan jamban maka motivasi akan tumbuh bagi masyarakat yang belum memliki dan menggunakan jamban keluarga yang sehat sehingga terdorong untuk membangun dan menggunakan jamban keluarga tersebut ${ }^{19}$ 10,11.

Berdasarkan penelitian di desa Kedaung diketahui bahwa sosial ekonomi merupakan salah satu faktor yang mempengaruhi kepemilikan jamban di setiap rumah tangga karena rendahnya status sosial ekonomi dapat menghambat dalam kepemilikan jamban yang memenuhi syarat. Sebagian besar responden di Desa Kedaung memiliki tingkat pendidikan terakhir adalah Pendidikan dasar tamatan SD, dengan pekerjaan sebagai buruh tani namun sebagian besar rumah tempat tinggal mereka adalah rumah milik pribadi dengan berbagai bentuk, dari yang permanen, semi permanen hingga non permanen ${ }^{3,11}$. Sehinga faktor

tersebut sangat mempengaruhi dalam kepemilikan jamban keluarga yang sehat di Desa Kedaung Kecamatan Pardasuka tahun 2020.

Berdasarkan penelitian yang telah dilakukan di Desa Kedaung Kecamatan Pardasuka ini didapatkan masih banyaknya responden yang pengetahuannya masih kurang tentang jamban sehat. Pengetahuan merupakan merupakan faktor penting dalam upaya peningkatan pengelolaan jamban keluarga, karena dengan pengetahuan yang baik masyarakat semakin memahami betapa pentingnya jamban sehat dalam keluarga. Tidak hanya membangun atau memiliki namun harus digunakan dan dijaga kebersihannya. Pemeliharaan jamban keluarga sehat yang baik adalah lantai jamban hendaknya selalu bersih dan tidak ada genangan air, bersihkan jamban secara teratur sehingga ruang jamban selalu dalam keadaan bersih, didalam jamban tidak ada kotoran terlihat, tidak ada serangga seperti kecoak, lalat dan tikus berkeliaran, tersedia alat pembersih dan bila ada kerusakan segera diperbaiki. Dengan menjaga kesehatan lingkungan yang ada disekitar rumah, maka akan terbebas dari berbagai masalah kesehatan seperti timbulnya media bibit penyakit seperti diare, typhus, muntaber, disentri, cacingan dan gatal-gatal. Selain itu dapat menimbulkan pencemaran lingkungan pada sumber air dan bau busuk serta estetika di sekitar lingkungan $8,10,11$. 
Studi Deshmukh (2020) menyatakan bahwa untuk mengatasi masalah minimnya pemanfaatan jamban saniter di perdesaan adalah dengan cara menyediakan jamban rumah tangga dan jamban masyarakat yang berkualitas disertai dengan bekal untuk menumbuhkan kesadaran masyarakat tentang manfaat penggunaan jamban sanitasi ${ }^{20}$. Sementara itu penelitian Panda (2017) menunjukkan pada suatu masyarakat pedesaaan dimana mayoritas masyarakatnya $70,3 \%$ telah memiliki jamban di rumah mereka. Namun prevalensi buang air besar sembarangan di wilayah penelitian ditemukan juga masih ditemukan sebesar $23,2 \%$ dan sekitar $65,2 \%$ subjek penelitian tidak mengetahui tentang penyebaran penyakit akibat buang air besar di udara terbuka. Kesadaran tentang penyebaran penyakit akibat buang air besar sembarangan masih rendah ${ }^{21}$. Penelitian Britta Augsburg (2020) menunjukkan ternyata rumah tangga yang memiliki sanitasi menunjukkan pengeluaran konsumsi yang lebih tinggi. Peningkatan kepemilikan aset produktif dan pergeseran alokasi waktu merupakan pendorong potensial di balik peningkatan pengeluaran konsumsi ${ }^{21}$.

\section{KESIMPULAN DAN SARAN}

Faktor penghambat kepala keluarga dalam kepemilikan jamban keluarga adalah rendahnya motivasi, rendahnya sosial ekonomi dan pengetahuan yang kurang baik di Desa Kedaung Kecematan Pardasuka.

Adapun saran penelitian yaitu perlu meningkatkan program kegiatan promotif yang meningkatkan motivasi dan pengetahuan masyarakat dibidang kesehatan lingkungan dalam upaya kepemilikan jamban keluarga. Melakukan pelatihan yang berkesinambungan agar program kesehatan khususnya kesehatan lingkungan dapat berjalan sesuai apa yang menjadi harapan. Mengoptimalkan proses memantauan evaluasi sasaran dan pendamping kepada masyarakat, serta memberdayakan masyarakat setempat untuk tidak membuang air besar sembarangan di tempat terbuka dan membuat rencana kegiatan untuk meningkatkan sosial ekonomi masyarakat. Masyarakat berperan serta aktif dalam mengikuti kegiatan yang diadakan oleh petugas kesehatan atau tokoh masyarakat tentang peningkatan kesehatan lingkungan seperti pembangunan dan pemanfaatan jamban sehat keluarga dan program sanitasi total berbasis masyarakat dengan baik. Agar masyarakat dapat mandiri dalam menjaga kesehatan lingkungan mereka sendiri dan lingkungan sekitarnya. Peneliti selanjutnya, disarankan melakukan pendekatan dengan case control dan menambah variabel yang terkait faktor-faktor apa saja yang dapat menghambat kepala keluarga dalam kepemilikan jamban keluarga.

\section{DAFTAR PUSTAKA}

1. Kemenkes RI. Laporan Hasil Riset Kesehatan Dasar (Riskesdas) Indonesia tahun 2018. Jakarta; 2018.

2. Kemenkes RI. Monitoring dan Evaluasi. Jakarta: Kementerian Kesehatan Republik Indonesia; 2020.

3. Faidah DA, Sunarno JM. Gambaran Kepemilikan Jamban Sehat di Desa Kalitengah Kecamatan Purwanegara Kabupaten Banjarnegara Tahun 2018. Medsains. 2018;4(01):19-24.

4. Sayati D. Faktor-faktor yang Mempengaruhi Pemanfaatan Jamban Sehat di Wilayah Kerja Puskesmas 23 Ilir Palembang Tahun 2018. J 'Aisyiyah Med. 2018;2(Agustus 2018):57-68.

5. Pungut, Suning RKP. Strategi Kebijakan Peningkatan Penggunaan Jamban Untuk Keberlanjutan Sanitasi. Semin Nas dan Disk Panel Multidisiplin Has Penelit dan Pengabdi Kpd Masy. 2018;193-9.

6. Nurhayati E, Setiawati RT, Soedjono ES, Suswanto B, Warmadewanthi. Peningkatan Kualitas Sanitasi Kelurahan Keputih Melalui Bantuan Jamban Sehat Menuju Kecamatan Sukolilo ODF). J Purifikasi. 2019;19(1):37-46.

7. Setiyabudi Ragil \& Veronika Setyowati. Penyediaan Air Bersih, Penggunaan Jamban Keluarga, Pengelolaan Sampah, Sanitasi Makanan Dan Kebiasaan Mencuci Tangan Berpengaruh 1 Terhadap Kejadian Diare Umur 15-50 Th. MediSains J Ilm Ilmu-Ilmu Kesehat. 2016;14(02):18-31.

8. Suseno DP. Membangun Jamban Keluarga Mandiri Untuk Sanitasi Berstandar Kesehatan. 2019;1-15.

9. R. Devy S, R. Nadhiroh S, D. Rahmayanti R, Martini S. Gambaran Sarana Air Bersih dan Jamban Keluarga di Daerah Tertinggal Kabupaten Sampang. IPTEK J Proc Ser. 2017;3(5):5-10.

10. Widyastutik O. Faktor Yang Berhubungan Dengan Kepemilikan Jamban Sehat Di Desa Malikian, Kalimantan Barat. Ikesma. 2017;13(1).

11. Ma'ruf F. Faktor yang Mempengaruhi Rendahnya Partisipasi Masyarakat Terhadap Pelaksanaan Program Sanitasi Total Dan Pemasaran Sanitasi (STOPS) (Studi Pada 
Kegiatan Arisan Jamban Di Desa Penggaron, Kecamatan Mojowarno, Kabupaten Jombang. J Ilmu Adm Negara. 2015;3(3):1-16.

12. Novitry F, Agustin R. Determinan Kepemelikan Jamban Sehat di Desa Sukomulyo Martapura. AISYAH J Ilmu Kesehat. 2017;2(2):107-16.

13. Theresiana Y, Triayana L, Clara S. Determinants of Healthy Latrines Ownership in Working Area at Public Health Center of Suak Tapeh in Banyuasin Regency South Sumatra 2019. In: 2nd Sriwijaya International Conference of Public Health (SICPH 2019). 2020. p. 26876.

14. Linggar F, Rantetampang AL, Tingginehe $\mathrm{R}$, Mallongi A. The Factors Influencing Defecation Behavior in Toilet Pasca Community Led Total Sanitation at Wamesa Sub District Manokwari Selatan District. Int J Sci Healthc Res. 2019;4(March):88-99.

15. Hafid F, Djabu U, Udin, Nasrul. Efek Program SBABS Terhadap Pencegahan Stunting Anak Baduta di Kabupaten Banggai dan Sigi. Indones J Hum Nutr [Internet]. 2017;4(2):79-87. Available from: ijhn.ub.ac.id/index.php/ijhn/article/view/22 3

16. Chattopadhyay A, Sethi V, Nagargoje VP, Saraswat A, Surani N, Agarwal N, et al. WASH practices and its association with nutritional status of adolescent girls in poverty pockets of eastern India. BMC Womens Health. 2019;19(1):89.

17. Ngure FM, Humphrey JH, Mbuya MNN, Majo F, Mutasa K, Govha M, et al. Formative Research on Hygiene Behaviors and Geophagy among Infants and Young Children and Implications of Exposure to Fecal Bacteria. 2013;89(4):709-16.

18. Murti B. Desain dan ukuran sampel untuk penelitian kuantitatif dan kualitatif di bidang kesehatan. 1st ed. Murti B, editor. Yogyakarta: Gadjah Mada University; 2010. 1-153 p.

19. Egziabher TBG, Edwards S. Qualitative and Quantitative Analysis of Volatile Constituents from Latrines. Africa's potential Ecol Intensif Agric. 2013;53(9):1689-99.

20. Deshmukh S, Ghooli S, Kurle RS. A study to assess the awareness and practice regarding utilization of sanitary toilet in the rural villages of Kalaburagi district. Int $\mathbf{J}$ Community Med Public Heal [Internet]. 2020 Feb 27;7(3):1184. Available from: https://www.ijcmph.com/index.php/ijcmph/ article/view/5834

21. Panda PS, Chandrakar A, Soni GP.
Prevalence of open air defecation and awareness and practices of sanitary latrine usage in a rural village of Raipur district. Int J Community Med Public Heal [Internet]. 2017 Aug 23;4(9):3279. Available from: http://www.ijcmph.com/index.php/ijemph/a rticle/view/1671 